\title{
Pengaruh Efektifitas Kerja terhadap Kinerja Pegawai pada Kantor Badan Penyelenggara Jaminan Sosial
}

\author{
Nelson \\ Universitas Sang Bumi Ruwa Jurai \\ nelson12@saburai.co.id
}

\begin{abstract}
Abstrak.
Tujuan Penelitian ini adalah untuk mengetahui berapa besar pengaruh efektivitas kerja terhadap kinerja pegawai pada Kantor Badan Penyelanggara Jaminan Sosial Kota Bandar Lampung. Jenis penelitian ini menggunakan kuantitatif dengan analisis deskriptifyaitu yang bermaksud membuat pemaparan secara sistimatis, faktual, dan akurat mengenai fakta - fakta dan sifat - sifat populasi tertentu. Analisis kualitatif dengan menggunakan table dan analisis kuantitaif menggunakan regresi linear sederhana Penelitian ini menggunakan 31 responden penelitian. Ada dua variabel dalam penelitian ini yaitu: Variabel bebas (X) dan variable terikat (Y). Dari hasil pengolahan data telah berhasil ditemukan jawaban hipotesis yakni sebagai berikut; terdapat pengaruh efektifitas $(\mathrm{X})$ terhadap kinerja $(\mathrm{Y})$ sebesar 95,9\%. Terdapat pengaruh antara efektifitas (X), kinerja pegawai (Y) dengan, dengan tingkat pengaruh sebesar 95,9\% yang berarti bahwa efektifitas dan kinerja pegawai memberikan pengaruh dan sisanya dipengaruhi variabel lain yang tidak masuk dalam penelitian ini.
\end{abstract}

Kata kunci: Efektifitas, Kinerja Pegawai, Badan Penyelenggaea Jaminan Sosial

\begin{abstract}
.
The purpose of this study was to determine how much influence the effectiveness of work on employee performance at the Office of the Social Security Organizing Agency Bandar Lampung City. This type of research uses quantitative with descriptive analysis which intends to make systematic, factual, and accurate exposure of the facts and characteristics of certain populations. Qualitative analysis using tables and quantitative analysis using simple linear regression This study used 31 research respondents. There are two variables in this study, namely: Independent variable $(X)$ and dependent variable $(Y)$. From the results of data processing has been found the answers to the hypothesis are as follows; there is an effect of effectiveness (X) on performance $(Y)$ of $95.9 \%$. There is an influence between effectiveness $(X)$, employee performance $(Y)$ with, with a level of influence of $95.9 \%$ which means that the effectiveness and performance of employees gives effect and the rest is influenced by other variables not included in this study.
\end{abstract}

Keywords:Effectiveness, EmployeePerformance, Badan Penyelenggaea Jaminan Sosial

\section{PENDAHULUAN}

Pada era seperti saat ini mengelola sumber daya manusia (SDM) menjadi sangat penting. Pada kenyataannya para anggota organisasi merupakan faktor pengaruh yang paling penting karena perilaku merekalah yang dalam jangka panjang akan memperlancar atau merintangi tercapainya tujuan organisasi. Pekerja merupakan sumber daya yang langsung berhubungan dengan pengelolaan semua sumber daya yang ada di dalam organisasi(Karambut, 2017). oleh sebab itu perilaku pekerja sangat berpengaruh terhadap pencapaian tujuan organisasi.

Menurut UU Nomor 40 Tahun 2004 dan Undang-Undang Nomor 24 Tahun 2011 Badan Penyelenggara Jaminan Sosial atau BPJS merupakan lembaga yang dibentuk untuk menyelenggarakan program Jaminan Sosial Nasional dan program BPJS Kesehatan ini resmi mulai berlaku pada tanggal 1 Januari 2014. Namun setelah dibentuknya BPJS Kesehatan terjadi sejumlah masalah di berbagai daerah. Masalah tersebut seperti masih banyak kalangan yang kurang paham dengan 
program yang diselenggarakan BPJS Kesehatan yaitu Program Jaminan Kesehatan Nasional (JKN). Bukan hanya peserta, pihak pemberi layanan kesehatan juga banyak yang tidak paham tentang program baru tersebut.(Widada et al., 2017).

Setiap organisasi akan selalu berusaha semaksimal mungkin melaksanakan tugas dan pokoknya dalam pencapaian tujuan yang telah ditetapkan. Oleh karena itu selayaknya organisasi selalu mengupayakan dan memelihara efektivitas kerja karyawan yang tinggi.(Nuzleha et al., 2019)

Efektivitas berasal dari kata efektif yaitu suatu pekerjaan dikatakan efektif jika dapat menghasilkan atau mencapai sasaran dan diselesaikan tepat pada waktunya sesuai dengan rencana yang telah ditetapkan.(Murti, 2013) Efektivitas merupakan suatu keadaan yang menunjukkan keberhasilan kerja yang ditetapkan.Efektivitas kerja adalah penyelesaian pekerjaan tepat pada waktu yang telah ditentukan, artinya pelaksanaan suatu tugas ditandai baik atau tidak, sangat tergantung pada penyelesaian tugas tersebut bagaimana cara melaksanakannya, dan berapa biaya yang dikeluarkan untuk itu. (Siti Maysita, 2016:236). Dari pengertian menurut para ahli tersebut dapat disimpukan bahwa efektivitas kerja adalah suatu penyelesaian pekerjaan yang mencapai sasaran atau tepat pada waktunya.

Faktor-faktor yang dapat menentukan efektivitas kerja pegawai berhasil dilakukan dengan baik atau tidak dipengaruhi oleh gaya kepemimpinan. Tugas pegawai dapat berjalan dengan baik apabila dilakukan pemberitahuan (komunikasi) tentang pendelegasian tugas/tanggung jawab serta adanya evaluasi kerja dari pimpinan.Faktor yang mempengaruhi efektivitas kerja adalah waktu, tugas, produktivitas, evaluasi, pengawasan, motivasi, fasilitas kerja.(Karambut, 2017)
Pada umumnya efektivitas sering dihubungkan dengan efisiensi dalam pencapaian tujuan organisasi. Padahal suatu tujuan atau saran yang telah tercapai sesuai dengan rencana dapat dikatakan efektif, tetapi belum tentue fisien.Walaupun terjadi suatu peningkatan efektivitas dalam suatu organisasi maka belum tentu itue fisien jelasnya, jika sasaran atau tujuan telah tercapai sesuai dengan yang direncanakan sebelumnya dapat dikatakan efektif. Jadi bila suatu pekerjaan itu tidak selesai sesuai waktu yang telah di mencapai sasaran yang telah ditetapkan dan adanya keterkaitan antara nilai - nilai yang bervariasi.

Pelatihan adalah upaya yang dilakukan organisasi untuk memperbaiki efisiensi dan efektivitas kerja pegawai dalam melaksanakan pekerjaan guna mencapai tujuan program kerja yang telah ditetapkan dengan indikator: perubahan pengetahuan, perubahan sikap, perubahan keterampilan, kemampuan melakukan perbaikan, dan kemampuan meningkatkan produktivitas kerja.(Manurung et al., 2018) Terciptanya lingkungan kerja yang nyaman, aman dan menyenangkan merupakan salah satu cara perusahaan untuk dapat meningkatkan kinerja.(Rahmawanti, 2014) salah satu faktor dari efektivitas kerja adalah fasilitas kerja yang termasuk dalam lingkungan kerja.

Fenomena yang terjadi pada Kantor Badan Penyelenggara Jaminan Sosial (BPJS) Ketenagakerjaan Lampung adalah Masih adanya beberapa pegawai yang kualitas pelayanannya menurun sedangkan Pemberian Pendidikan tetap didapatkan. Masih adanya pegawai yang mempunyai Pelatihan kerja yang rendah, hal ini terlihat dari kurangnya semangat dan gairah kerja.Masih dirasakan kurangnya Pelatihan kerja yang diberikan pimpinan baik Pelatihan kerja material maupun Pelatihan kerja non material. Pelatihan kerja belum maksimal, hal ini ditunjukkan dengan masih banyak pekerjaan yang tidak selesai tepat 


\section{EKOMBIS Sains}

pada waktunya karena pelatihan kerja yang diberikan tidak diaplikasikan pada pelaksanaan pekerjaan. Kualitas pelayanan belum optimal, pelayanan masih terasa lambat dan terbentur dengan birokrasi yang panjang dan berbelit-belit.

$$
\text { Secara terminology kinerja }
$$

merupakan terjemahan dari kata

performance. Kata kinerja tersusun dari dua kata yaitu "kinetika" yang berarti kemampuan atau prestasi dan kata "kerja". Dengan demikian dalam kinerja terkandung pengertian kemampuan kerja atau prestai kerja (Josiah et al., 2019). Kinerja pegawai merupakan kinerja yang dilakukan untuk memberikan pelayanan kepada konsumen. Pelayanan merupakan segala bentuk layanan yang diberikan pada dasarnya bertujuan untuk memenuhi kepentingan umum atau kepentingan perorangan yang bertumpu pada hak dasar sebagai warga negara. (Hidayati \& Ermiyanto, 2017). Penilaian kinerja pada dasarnya merupakan factor kunci guna mengembangkan suatu organisasi secara efektif dan efisien, karena adanya kebijakan atau program yang lebih baik atas sumber daya manusia yang ada dalam organisasi.(Erawati et al., 2017)

Mengukur kinerja dimaksudkan untuk menilai hasil dan keluaran yang dihasilkan oleh seorang karyawan dalam kurun waktu tertentu. Prawirosentono yang dikutip oleh Deni menerangkan kinerja dapat diukur dengan beberapa indicator yaitu: 1) Efektifitas yaitu bila tujuan kelompok dapat dicapai dengan kebutuhan yang direncanakan. 2) Tanggung jawab Merupakan bagian tak terpisahkan atau sebagai akibat kepemilikan wewenang. 3) Disiplin Yaitu taat pada hukum dan aturan yang berlaku. Disiplin karyawan adalah ketaatan karyawan yang bersangkutan dalam menghormati perjanjian kerja dengan organisasi dimana dia bekerja. 4) Inisiatif Berkaitan dengan daya pikir, Sifat inisiatif sebaiknya mendapatkan perhatian atau tanggapan dari organisasi dan atasan dengan baik. Dengan perkataan lain inisiatif karyawan merupakan daya dorong kemajuan yang akhirnya akan mempengaruhi kinerja karyawan.(Deni, 2014)

Penelitian sebelumnya menunjukan bahwa motivasi berpengaruh pada kinerja pegawai kantor sekretariat daerah Kabupaten Gunung Kidul.(Amin, 2015).Penelitian lain menunjukan bahwa efektifitas kerja dapat ditingkatkan melalui pelaksanaan pelatihan yang relevan, pelaksanaan penjaminan mutu secara baik, perbaikan kompetensi pedagogic dan penguatan efikasi diri.(Manurung et al., 2018).Penelitian juga membuktikan bahwa terdapat pengaruh yang cukup kuat dari kepuasan kerja terhadap kinerja pegawai.(Sari \& Hadijah, 2016). Dari beberapa penelitian tersebut dapat dituliskan bahwa persamaan penelitian sebelumnya dengan penelitian yang akan teliti adalah sama-sama membahas tentang kinerja kerja. Perbedaanya pada metodelogi dan pada faktor yang mempengaruhi peneliti disini ingin mengetahui tentang pengaruh efektivitas kerja terhadap kinerja pegawai.

Berdasarkan uraian tersebut, peneliti tertarik untuk mengatahui adakah pengaruh efektivitas kerja terhadap kinerja pegawai pada kantor badan penyelenggara jaminan sosial Bandar Lampung.

\section{METODE PENELITIAN}

Dalam penelitian ini yang menjadi Objeknya adalah :Kantor Badan Penyelenggara Jaminan Sosial Kota Bandar Lampung. Kantor ini terletak di Jl. Zainal Abidin Pagar Alam No.35 Rajabasa Bandar Lampung. Pelaksanaan penelitian mulai bulan April sampai Agustus 2016.

a. Penelitian ini dilakukan secara langsung ke Kantor Badan Penyelenggara Jaminan Sosial Kota Bandar Lampung dengan langkah-langkah :

b. Observasi, yaitu pengamatan langsung guna menguji kebenaran hasil 


\section{EKOMBIS Sains}

wawancara yang telah dilakukan sebelumnya hingga diperoleh bukti dan fakta empiris dari perusahaan.

c. Wawancara, dilakukan dengan cara bertemu langsung dan bertanya secara langsung dengan pegawai pada Kantor Badan Penyelenggara Jaminan Sosial Kota Bandar Lampung.

d. Kuesioner, yaitu melakukan penyebaran daftar pertanyaan yang diajukan kepada pegawai pada Kantor Badan Penyelenggara Jaminan Sosial Kota Bandar Lampung.

e. Dokumentasi, yaitu merupakan Teknik pengumpulan data yang dilakukan dengan cara mencari data mengenai halhal yang berhubungan dengan penelitian.

Analisis kualitatif dilakukan dengan analisis tabel tunggal atau secara parsial yang menggambarkan kriteria masingmasing variabel independent, dalam penelitian ini yaitu varibel efektivitas (X).

Kriteria masing-masing variabel pada analisis tabel mengacu pada interval skor dengan rumus sebagai berikut :

$$
I=\frac{N T-N R}{J I}
$$

Keterangan :

I = Lebar interval

NT $=$ Nilaitertinggi

$\mathrm{NR}=$ Nilaiterendah

$\mathrm{JI}=$ Jumlah interval

Analisis kuantitatif yang digunakan dalam penelitian ini bertujuan untuk mengetahui pengaruh Efektivitas Kerja terhadap Kinerja pada Kantor Badan Penyelenggara Jaminan Sosial Kota Bandar Lampung.

Rumus regresi linear sederhana yang digunakan dalam penelitian ini adalah sebagai berikut :

$$
\hat{\mathrm{Y}}=a+b 1 X 1+e
$$

Keterangan :

$\hat{Y} \quad=$ Variabel Dependen

$a \quad=$ Intercept (harga Konstan)

$b \quad=$ Koefisien Regresi

$X \quad=$ Variabel Independen

(Sugiyono, 2014)

Dan untuk menguji signifikansi digunakan Uji $\mathrm{t}$ dengan rumus sebagai berikut :

$$
t_{\text {hitung }}=\frac{\sqrt[r]{n-2}}{\sqrt{1-r^{2}}}
$$

Dimana :

$$
\begin{array}{ll}
\mathrm{t}_{\text {hitung }} & =\text { Nilai } \mathrm{t} \\
\mathrm{r} & =\text { Koefisien Korelasi } \\
\mathrm{n} & =\text { Jumlah responden }
\end{array}
$$

(Sugiyono, 2014)

Kriteria untuk Uji t adalah sebagai berikut :

a) Jikat ${ }_{\text {hitung }}>t_{\text {tabelmaka }} \mathrm{Ha}$ diterimadan Ho ditolak.

b) Jika $t_{\text {hitung }} \leq t_{\text {tabel }}$ maka Ha ditolak dan Ho diterima.

Taraf signifikan dalam penelitian ini digunakan $\alpha=0,05$ atau $5 \%$.

Yang dimaksud dengan Hipotesis nol (Ho) dan Hipotesis alternatif (Ha) adalah

$$
\begin{aligned}
\text { Ho }= & \mathrm{r}_{1} \leq 0=\text { Berarti tidak ada pengaruh } \\
& \text { antara efektivitas kerja terhadap } \\
& \text { kinerja }
\end{aligned}
$$

$\mathrm{Ha}=\mathrm{r}_{1}>0=$ Berarti ada pengaruh antara efektivitas kerja terhadap kinerja HASIL DAN PEMBAHASAN

\section{Deskripsi Responden berdasarkan Tingkat Pendidikan}

Karakteristik pegawai yang menjadi subyek dalam penelitian ini menurut Tingkat Pendidikan ditunjukkan dalam Tabel 2 dibawah ini :

\section{Tabel 1. Distribusi frekuensi Responden Berdasarkan Tingkat Pendidikan}




\section{EKOMBIS Sains}

\begin{tabular}{cccc}
\hline No & Keterangan & Frekuensi & Persentase \\
\hline 1 & SMP/SMA & 8 & $25.81 \%$ \\
\hline 2 & D2/ D3 & 6 & $19.35 \%$ \\
\hline 3 & S1 & 17 & $54.84 \%$ \\
\hline Total & & 31 & $100,0 \%$
\end{tabular}

Sumber : Data diolah, 2016

Karakteristik responden dilihat dari latar belakang pendidikan didominasi oleh S1, yakni sebanyak 17 orang dengan tingkat persentase sebesar 54,84\%, kemudian tingkat pendidikan SMP/SMA/SMK sebanyak 8 orang dengan tingkat persentase sebesar $25,81 \%$, tingkat pendidikan D2/D3 sebanyak 6 orang dengan tingkat persentase sebesar $19.35 \%$. Secara visualisasi diagram Tingkat Pendidikan responden dapat dilihat pada Gambar 1 sebagai berikut :

\section{Tingkat Pendidikan}

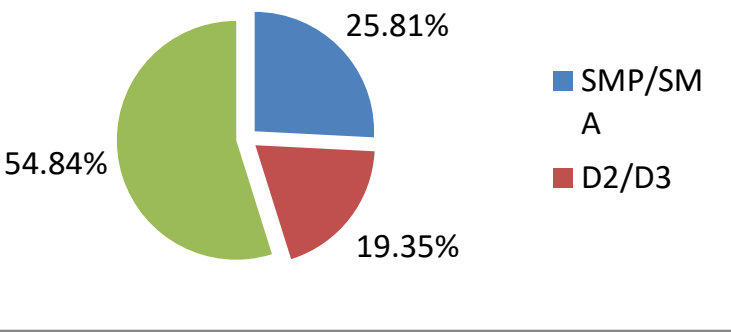

Sumber : Data diolah, 2016

\section{Gambar 1. Diagram Pie Tingkat Pendidikan Responden}

\section{Deskripsi Responden Berdasarkan Masa Kerja}

Karakteristik pegawaiyang menjadi subyek dalam penelitian ini menurut Masa Kerja ditunjukkan dalam Tabel 2 dibawah ini

Tabel 2. Distribusi Frekuensi Responden Berdasarkan Masa Kerja

\begin{tabular}{clcc}
\hline No & Keterangan & Frek & Persentase \\
\hline 1 & 1 tahun & - & $0 \%$ \\
\hline 2 & $1-5$ tahun & 13 & $41.94 \%$ \\
\hline 3 & $6-10$ tahun & 4 & $12.90 \%$ \\
\hline 4 & $>10$ Tahun & 14 & $45.16 \%$ \\
\hline \multicolumn{2}{l}{ Total } & 31 & $100,0 \%$ \\
\hline
\end{tabular}

Sumber : Data diolah, 2016

Karakteristik responden dilihat dari masa kerja didominasi oleh responden dengan masa kerja diatas 10 tahun yakni sebanyak 14 orang dengan tingkat persentase sebesar 45,16\%, masa kerja 1 5 tahun sebanyak 13 orang dengan tingkat persentase sebesar41.94 \% dan masa kerja 610 tahun memiliki jumlah 4 orang dengan tingkat persentase $12.90 \%$. Secara visualisasidiagram masa kerja responden dapatdilihat pada Gambar 2 sebagaiberikut:

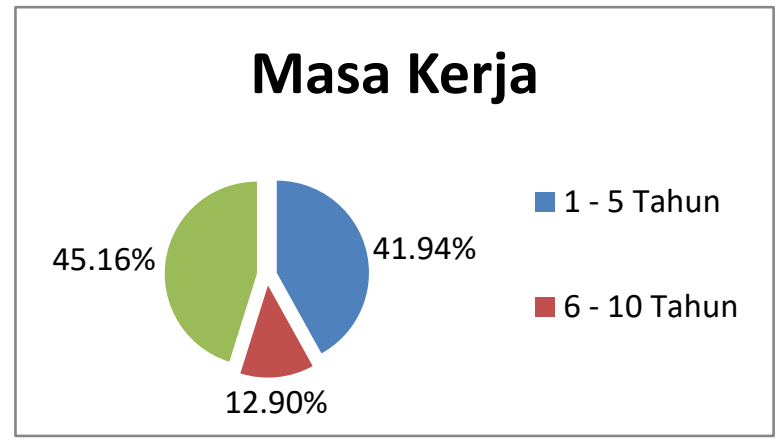

Sumber : Data diolah, 2016

Gambar 2. Diagram Pie Masa Kerja

Analisis Kuantitatif

Berikut data distribusi hasil tanggapan responden variabel Efektifitas Kerja (X), dan Kinerja (Y) secara keseluruhan.

Tabel 3. Distribusi Data Efektifitas Kerja (X)

\begin{tabular}{llll}
\hline No & Skor & Kategori & Frek \\
\hline
\end{tabular}




\begin{tabular}{lllll}
\hline 1 & $41-50$ & Sangat Baik & 10 & $33,3 \%$ \\
\hline 2 & $31-40$ & Baik & 17 & $54,4 \%$ \\
\hline 3 & $21-30$ & Sedang & 4 & $12,3 \%$ \\
\hline 4 & $11-20$ & Buruk & - & - \\
\hline 5 & $0-10$ & Sangat Buruk & - & - \\
\hline JUMLAH & & 31 & $100 \%$ \\
\hline
\end{tabular}

Sumber :data diolah, 2016

Dari 31 orang responden penelitian, Efektifitas Kerja (X) pada Badan Penyelenggara Jaminan Sosial (BPJS) Bandar Lampung dalam kategori "sangat baik" ada 10 orang $(33,3 \%)$, yang menyatakan "baik" ada 17 orang $(54,4 \%)$, dan yang menyatakan "sedang" ada 4 orang $(12,3 \%)$. Sedangkan responden yang menyatakan "buruk" ada 0 orang $(0 \%)$ dan yang menyatakan "sangat buruk" ada 0 orang $(0 \%)$.

Tabel 4. Distribusi Data Kinerja (Y)

\begin{tabular}{cclcc}
\hline No & Skor & Kategori & Frek & $\%$ \\
\hline 1 & $41-50$ & $\begin{array}{l}\text { Sangat } \\
\text { Baik }\end{array}$ & 9 & $28,1 \%$ \\
\hline 2 & $31-40$ & Baik & 19 & $61,4 \%$ \\
\hline 3 & $21-30$ & Sedang & 3 & $10,5 \%$ \\
\hline 4 & $11-20$ & Buruk & - & - \\
\hline 5 & $0-10$ & $\begin{array}{l}\text { Sangat } \\
\text { Buruk }\end{array}$ & - & - \\
\hline JUMLAH & & 31 & $100 \%$ \\
\hline
\end{tabular}

Sumber :Data diolah, 2016

Dari 31 orang responden penelitian, Kinerja (Y) pada Badan Penyelenggara Jaminan Sosial (BPJS) Bandar Lampung dalam kategori "sangat baik" ada 9 orang $(28,1 \%)$, yang menyatakan "baik" ada 19 orang $(61,4 \%)$, dan yang menyatakan "sedang" ada 3 orang (10,5\%). Sedangkan responden yang menyatakan "buruk" ada 0 orang $(0 \%)$ dan yang menyatakan "sangat buruk" ada 0 orang $(0 \%)$.

Berdasarkan hasil jawaban responden di atas, dapat dijelaskan bahwa secara umum Efektifitas Kerja dan Kinerja pada Badan Penyelenggara Jaminan Sosial (BPJS) Bandar Lampung dalam kondisi baik. Kecenderungan jawaban yang secara

dominan menggambarkan kondisi yang baik ini tentunya bila semakin ditingkatkan akan mendorong Kualitas Pelayanan yang tinggi pada Badan Penyelenggara Jaminan Sosial (BPJS) Bandar Lampung.

\section{Pengaruh Efektivitas Terhadap Kinerja Karyawan}

Dari hasil penelitian dinyatakan bahwa Efektifitas Kerja pada Badan Penyelenggara Jaminan Sosial (BPJS) Bandar Lampung dalam kategori baik. Hasil perhitungan tingkat korelasi antara variabel Efektifitas Kerja (X) dengan Kinerja (Y) sebesar 0,979 termasuk dalam kategori sangat kuat yakni $(0,800-0,100)$. Besarnya koefisien Determinasi antara Efektifitas Kerja terhadap Kinerja adalah $=95,9 \%$. Uji hipotesis parsial melalui uji t (test) diperoleh nilai $t_{\text {hitung }}$ antara Efektifitas Kerja terhadap Kinerja sebesar $=35,938$ dan $t_{\text {hitung } 35,938>}$ $t_{\text {tabel }}$ 1,6720. Persamaan regresi antara Efektifitas Kerja dan Kinerja Badan Penyelenggara Jaminan Sosial (BPJS) Bandar Lampung adalah sebesar $\mathrm{Y}=1,821$ $+0,918 \mathrm{X}_{1}$, yang menunjukkan setiap kenaikan satu point dari variabel Efektifitas Kerja akan diikuti oleh naiknya variabel Kinerja pada Badan Penyelenggara Jaminan Sosial (BPJS) Bandar Lampung sebesar = 0,918 point. Hal ini sejalan dengan penelitian Yusro Hakimah yang hasil penelitianbahwa Efektivitas Kerja dan Motivasi Kerja dapat dipengaruhi oleh Kinerja Karyawan dengan regresi berganda persamaan $\mathrm{Y}=13.744+0,305 \mathrm{X} 1+0,339$ $\mathrm{X} 2$. (Hakimah, 2019). Dengan demikian bahwa bahwa efektivitas kerja berpengaruh pada kinerja seseorang ini sesuai dengan teori bahwa kinerja dapat diukur dengan beberapa indikator salah satunya adalah efektifitas

\section{KESIMPULAN DAN SARAN}

\section{Kesimpulan}




\section{EKOMBIS Sains}

Adapun kesimpulan dari penelitian ini adalah. Koefisien Determinasi $(\mathrm{KD})=\mathrm{R}^{2}=$ 0,959=95,9\%. Dapat disimpulkan bahwa variabel Efektifitas Kerja (X) menjelaskan variasi perubahan terhadap variabel Kinerja (Y) Badan Penyelenggara Jaminan Sosial (BPJS) Bandar Lampung sebesar 95,9\%, sedangkan sisanya dijelaskan oleh faktor lain yang tidak dikaji dalam penelitian ini. Y $=1,821+0,918 \mathrm{X}$, yang artinya setiap kenaikan satu point daripada variabel Efektifitas Kerja akan diikuti oleh naiknya variabel Kinerja pegawai Badan Penyelenggara Jaminan Sosial (BPJS) Bandar Lampung sebesar 0,918 point.

Dari hasil penelitian dinyatakan bahwa Efektifitas Kerja pada Badan Penyelenggara Jaminan Sosial (BPJS) Bandar Lampung dalam kategori baik. Hasil perhitungan tingkat korelasi antara variabel Efektifitas Kerja (X) dengan Kinerja (Y) sebesar 0,979 termasuk dalam kategori sangat kuat yakni $(0,800-0,100)$. Besarnya koefisien Determinasi antara Efektifitas Kerja terhadap Kinerja adalah $=95,9 \%$. Uji hipotesis parsial melalui uji t (test) diperoleh nilai $t_{\text {hitung }}$ antara Efektifitas Kerja terhadap Kinerja sebesar $=35,938$ dan thitung 35,938> $t_{\text {tabel }}$ 1,6720. Persamaan regresi antara Efektifitas Kerja dan Kinerja Badan Penyelenggara Jaminan Sosial (BPJS) Bandar Lampung adalah sebesar $\mathrm{Y}=1,821$ $+0,918 \mathrm{X}_{1}$, yang menunjukkan setiap kenaikan satu point dari variabel Efektifitas Kerja akan diikuti oleh naiknya variabel Kinerja pada Badan Penyelenggara Jaminan Sosial (BPJS) Bandar Lampung sebesar = 0,918 point.

\section{Saran}

Berdasarkan hasil penelitian dan kesimpulan, maka peneliti memberikan saran :

1. Padaefektifitas kerja yang perlu mendapat perhatian adalah pegawai mengeluh terhadap pekerjaan yang diemban, hal ini dapat ditingkatkan dengan memberikan motivasi kepada pegawai agar selalu mengerjakan tupoksi dengan penuh tanggung jawab dan merupakan kewajiban terhadap setiap pegawai untuk menyelesaikan semua pekerjaan.

2. Pada variabel kinerja pegawai yang perlu ditingkatkan adalah kondisi lingkungan kerja yang nyaman. Untuk saat ini kondisi kerja terutama ruangan kurang nyaman, hal ini membuat kinerja pegawai menurun karena merasa tidak betah berlama-lama diruangan. Solusi untuk hal ini adalah merenovasi ruangan agar kondisi menjadi nyaman dan pegawai betah bekerja dalam ruangan.

3. Hasil penelitian ini menunjukan bahwa efektivitas kerja berpengaruh pada kinerja pegawai. Namun dari perhitungan koefisien determinasi membuktikan bahwa ada faktor-faktor lain yang mempengaruhi kinerja pegawai kantor. Oleh karena itu diharapkan bagi peneliti selajutnya memberikan kontribusi tentang yang mempengaruhi kinerja pegawai kantor.

\section{DAFTAR PUSTAKA}

Amin, N. M. (2015). Pengaruh Kompetensi Terhadap Kinerja Pegawai di Sekretariat Daerah Kabupaten Sidenreng Rappang. Fakultas Ilmu Sosial Dan Ilmu Politik Jurusan Ilmu Admimistrasi Program Studi Administrasi Negara.

Deni, M. (2014). Pengaruh Pendidikan dan Pelatihan, Motivasi serta Budaya Organisasi terhadap Kinerja Pegawai Distrik Navigasi Kelas I Palembang. Jurnal Ilmu Manajemen Universitas Muhammadiyah Palembang, 4(1), 1$14 . \quad$ https://doi.org/DOI: https://doi.org/10.32502/jimn.v4i1.255

Erawati, I., Darwis, M., \& Nasrullah, M.(2017). Efektivitas Kinerja Pegawai 


\section{EKOMBIS Sains}

pada Kantor Kecamatan Pallangga Kabupaten Gowa. Jurnal Office. https://doi.org/10.26858/jo.v3i1.3450

Hakimah, Y. (2019). Analisis Kebutuhan Energi Listrik Danprediksi Penambahan Pembangkit Listrik Di Sumatera Selatan. Jurnal DESIMINASI TEKNOLOGI.

https://doi.org/10.1017/CBO97811074 15324.004

Hidayati, S. N., \& Ermiyanto, A. (2017). Analisis Faktor Motivasi Intrinsik dan Motivasi Ekstrinsik Pengaruhnya terhadap Kinerja Karyawan dengan Kepuasan Kerja sebagai Mediasi. Jurnal Maksipreneur: Manajemen, Koperasi, Dan Entrepreneurship. https://doi.org/10.30588/jmp.v7i1.320

Josiah, T., Novalia, \& Wuandari, A. U. 2019. Pengaruh Kemampuan Dan Motivasi Terhadap Kinerja Pegawai Di Sekretariat Penggerak Pkk Kota Bandar Lampung. Jurnal Ekonomi, Keuangan Dan Bisnis, 4(No 2), 915.

Karambut, A. C. (2017). Pengaruh Keselamatan Dan Kesehatan Kerja Terhadap Efektivitas Kerja Pada Pt. Asri Griya Utama, Project Holland Village Manado. Jurnal Manis Vol. 1. No2.

Manurung, S., Hidayat, R., Patras, Y. E., \&Fatmasari, R. (2018). Peningkatan Efektivitas Kerja melalui Perbaikan Pelatihan, Penjaminan Mutu, Kompetensi Akademik dan Efikasi Diri dalam Organisasi Pendidikan. MANAGERIA: Jurnal Manajemen Pendidikan Islam. https://doi.org/10.14421/manageria.20 18.31-04

Murti, N. (2013). Pengaruh Motivasi Dan Disiplin Terhadap Efektivitas Kerja Karyawan (Studi Pada Karyawan Pt.
Pln (Persero) Distribusi Jawa Timur Area Pelayanan dan Jaringan Malang). Jurnal Administrasi Bisnis S1 Universitas Brawijaya, 6(2), 78049.

Nuzleha, Yamin, Y. Y., \& Novalia. (2019). Pengaruh Efektifitas Kerja Terhadap Kinerja Pegawai Pada Kantor Badan Penyelenggara Jaminan Sosial Bandar Lampung. Ekombis Sains Jurnal Ekonomi Keuanga Dan Bisnis Universitas Sang Bumi Ruwa Jurai, 4 No. 1, 17-26.

Rahmawanti, N. P. (2014). Pengaruh Lingkungan Kerja Terhadap Kinerja Karyawan ( Studi pada Karyawan Kantor Pelayanan Pajak Pratama Malang Utara ).Jurnal Administrasi Bisnis (JAB)8(2), 1-9.

Sari, R. N. I., \& Hadijah, H. S .(2016). Peningkatan Kinerja Pegawai Melalui Kepuasan Kerja Dan Disiplin Kerja. Jurnal Pendidikan Manajemen Perkantoran.https://doi.org/10.17509/j pm.v1i1.3389

Sugiyono. (2017). Metode Penelitian Kuantitatif Kualitatif dan $R \& D$. Alfabeta.

Widada, T., Pramusinto, A., \& Lazuardi, L. (2017). Peran Badan Penyelenggara Jaminan Sosial (Bpjs) Kesehatan Dan Implikasinya Terhadap Ketahanan Masyarakat (Studi Di Rsud Hasanuddin Damrah Manna Kabupaten Bengkulu Selatan, Provinsi Bengkulu). Jurnal Ketahanan Nasional.https://doi.org/10.22146/jkn. 26388 